\title{
PRIMO LEVI: A QUÍMICA ENTRE LITERATURA E CIÊNCIA
}

\section{PRIMO LEVI: THE CHEMISTRY BETWEEN LITERATURE AND SCIENCE}

Aislan Camargo Maciera ${ }^{25}$

RESUMO: Primo Levi (1919-1987), italiano de origem judaica, antifascista e químico de formação, passa quase um ano de sua vida como prisioneiro em um dos campos de concentração de Auschwitz. Preso como partigiano, deportado como judeu, e sobrevivente por acaso, Levi faz daquela experiência, o ponto de partida de sua literatura. Sua grande vocação narrativa faz com que cultive os mais diversos gêneros ao longo de sua carreira. A análise da obra literária de Levi, obrigatoriamente, deve considerar dois aspectos, que estão na gênese e na construção de seus escritos: o primeiro é a origem de sua literatura, nascida da experiência como prisioneiro e da observação daquele universo; o segundo é a sua formação, pois, como químico, o olhar que dirigia ao mundo era determinado pelos preceitos da ciência que escolheu. $\mathrm{O}$ artigo pretende expor uma análise da literatura de Levi a partir da relação que ela estabelece com a ciência, com a técnica e, mais especificamente, com a química. As referências para a análise são suas entrevistas e ensaios a respeito do tema, bem como o livro que mais claramente representa a relação entre ciência e literatura em sua obra: A tabela periódica. Dessa forma, conclui-se que nenhuma página escrita pelo autor está dissociada de sua formação científica, e isso influencia diretamente o seu estilo, transformando-o em um dos principais representantes, na literatura universal, da relação entre "as duas culturas", como também em um dos principais prosadores da segunda metade do século XX.

Palavras-chave: Literatura italiana; Primo Levi; literatura e ciência; literatura e química.

${ }^{25}$ Doutor em Letras, na área de Língua, Literatura e Cultura Italianas. Pesquisador de Pós-Doutorado junto ao Departamento de Letras Modernas da FFLCH/USP. 
ABSTRACT: Primo Levi (1919-1987), Italian of Jewish origin, anti-fascist and chemist, spends nearly a year of his life as a prisoner in one of the Auschwitz concentration camps. Imprisoned as partigiano, deported as Jew, and survivor by chance, Levi makes of that experience the starting point of his literature. His great narrative vocation makes him cultivate the most diverse genres through his career. The analysis of Levi's literary work must necessarily consider two aspects that lie in the genesis and construction of his writings: the first is the origin of his literature, emerged from the experience as a prisoner and the observation of that universe; the second is his background, for as a chemist, the way he looked to the world was determined by the precepts of the science he chose. The article intends to present an analysis of Levi's literature from the relation that it establishes with science, technique and, more specifically, with chemistry. The references to the analysis are his interviews and essays on the subject, as well as the book that most clearly represents the relation between science and literature in his work: The Periodic Table. Therefore, it is possible to conclude that no page written by the author is dissociated from his scientific training, which directly influences his style, turning him into one of the main representatives in the universal literature of the relation between "the two cultures", as also in one of the main writers of the second half of the XX century.

Keywords: Italian literature; Primo Levi; literature and science; literature and chemistry.

\section{Breve leitura da relação ciência-literatura}

A discussão polêmica e complexa que permeia a relação entre ciência e literatura é fértil. Ao longo dos tempos envolveu escritores, críticos e teóricos através de debates suscitados, sobretudo, em épocas nas quais o esforço de fortalecer tal relação parece mais intenso. A cisão entre os dois campos é um advento moderno: começa a se estabelecer com a ciência moderna, na passagem do século XVI para o século XVII; reforçase com o Iluminismo do século XVIII; e consolida-se definitivamente no século XIX. Por isso, podemos dizer que as distinções em diferentes campos do saber, áreas do conhecimento e disciplinas - responsável por afastar a literatura da ciência, por exemplo - é um fenômeno moderno, muito discutido durante o século XX.

$\mathrm{Na}$ história da literatura, porém, mesmo depois do período de consolidação da ciência moderna, houve momentos em que a relação 
entre ciência e literatura foi retomada, discutida e reestabelecida. $\mathrm{Na}$ segunda metade do século XIX, o Positivismo foi responsável por impulsionar uma literatura que se baseava nas teorias (pseudo) científicas de sua época, e que procurava através de suas narrativas - principalmente - ser um documento de comprovação científica. A literatura naturalista e o romance experimental de Émile Zola são exemplos de um momento no qual a relação aqui discutida atinge uma cumplicidade significativa, atendendo uma quase necessidade da literatura se pautar e, consequentemente, ser determinada pela ciência da época. Ciência supervalorizada, travestida de verdade absoluta, pretensa explicação lógica e racional dos fenômenos naturais e da formação das sociedades humanas e que, naquele momento, voltava a se relacionar intimamente com a literatura.

A primeira metade do século XX representa o amadurecimento da relação entre literatura, ciência e tecnologia, no sentido de que as artes em geral não permanecem inertes às profundas e significativas transformações do período. No decorrer do "breve século", são fundamentais as descobertas que mudaram o modo do ser humano pensar a matéria e de se relacionar com o espaço e com o tempo. Além disso, as inovações tecnológicas entraram prepotentemente na vida das pessoas, modificando radicalmente a percepção da realidade e a capacidade de com ela interagir. Ao mesmo tempo em que as inovações tecnológicas passam a fazer parte do cotidiano, a linguagem científica, bem como as possibilidades que a ciência inaugura, são marcantes no pensamento humano ao longo do século XX.

Assim sendo, a arte acaba apropriando-se dessa nova realidade - o mundo mecanizado, a velocidade da vida nas grandes cidades, a crescente ruptura das relações pessoais -, para transmiti-la através de suas formas de expressão, seja expondo-a com entusiasmo, de maneira positiva, seja observando seus problemas, tratando-a de maneira negativa. Ocorre, portanto, uma divisão que, em linhas gerais, coloca de um lado cientistas, de outro, humanistas; de um lado, entusiastas do progresso, de outro, aqueles que não o veem de maneira tão positiva, ou simplesmente o execram; de um lado, integrados, de outro, apocalípticos ${ }^{26}$.

26 Termos utilizados por Umberto Eco. In: ECO, U. Apocalípticos e integrados. Trad. Pérola de Carvalho. São Paulo: Perspectiva, 2008, 6a edição. Nesse escrito, Eco separa aqueles que condenam os meios de comunicação de massa, chamando-os de apocalípticos, dos que os veem 
O entusiasmo pelo "progresso" científico e tecnológico é uma herança positivista, que sobrevive ao longo do século XX e invade as primeiras décadas do século XXI. Ela é, inclusive, uma das responsáveis por reforçar e consolidar a cisão entre as chamadas "duas culturas"27, fazendo com que houvesse ao longo da nossa história mais recente uma hierarquização dos campos e áreas do conhecimento, na qual aquilo que verdadeiramente poderia ser chamado de ciência - física, química, matemática, por exemplo - estaria num patamar superior às ditas disciplinas humanísticas. Tudo isso contribui para um arrefecimento do debate sobre os estudos da relação entre literatura e ciência, uma vez que a distinção entre as duas parece constituir uma barreira intransponível.

Ademais, a modernidade parece ter perdido o hábito de pensar na totalidade e na complexidade das inter-relações entre coisas e fatos diversos, não segmentados. A ciência moderna desenvolveu-se obedecendo a uma única ética - a de acumulação do conhecimento a qualquer custo -, determinando a cisão entre "as duas culturas”, a partir de uma focalização disciplinarmente restrita. Ao provocar tal cisão, a modernidade transforma o conhecimento que passa de uma época prédisciplinar, mas funcionalmente transdisciplinar, para uma era completamente feita de disciplinas isoladas que, aparentemente, pouco ou nada dialogam entre si. A tendência dominante da era moderna foi aquela da autonomia da ciência em relação a quaisquer construções filosóficas, teológicas ou metafísicas. Segundo Ceserani (2010, pp. 48-49), o conhecimento científico transformou-se em "coleta de dados, execução de experimentos de laboratório, elaboração e confirmação de dados estatísticos e quantitativos, divisão das áreas disciplinares”. Tais procedimentos, comuns no trabalho de físicos, biólogos e químicos, por exemplo, foram adotados também por algumas disciplinas das ciências humanas, como a história, a sociologia ou a economia. O que as levaram a isso foi exatamente o caráter científico dado a esses procedimentos.

com bons olhos, os integrados. Eco vai tratar não somente dos meios de comunicação de massa, como também da sociedade moderna que a eles deu origem. Utilizamos tal nomenclatura exatamente para pontuar a diferença entre aqueles que viam o avanço científico-tecnológico como algo extremamente prejudicial e danoso - os apocalípticos - e aqueles que o viam como irreversível e, ao mesmo tempo, o exaltavam - os integrados. ${ }^{27}$ Expressão de C. P. SNOW, em seu célebre ensaio de 1959. 
Dessa forma, modernamente, entende-se por ciência algo experimental e sujeito a reduções matemáticas, ao passo que a cultura literária e humanística parece, segundo o ponto de vista comum e dominante, afastar-se cada vez mais desse paradigma. Mas não podemos, sob pena de graves distorções, distanciar ciência e literatura. Muitos são os casos de autores e obras nos quais a penetração de temas científicos é evidente; ou aqueles, como Galileu, nos quais as obras, estritamente científicas, apresentam qualidades literárias; ou ainda, e mais profundamente, autores que estabelecem uma relação mais íntima entre o discurso literário e aquele científico, com a utilização de um em outro, como é o caso de Italo Calvino ou Primo Levi.

\section{Ciência e Literatura no contexto italiano do segundo pós-guerra}

$\mathrm{Na}$ Itália, o debate acerca da literatura e sua relação com a ciência parece não ter tido, em muitos casos, um tratamento adequado ao longo do século passado. Segundo Pierpaolo Antonello (2009, p. 5), enquanto em outros países, como Inglaterra e Estados Unidos, a partir dos anos oitenta, foi constituído um campo de estudo que se denomina "literature and science", o tema na península alterna poucos momentos de interesse dentre os quais podemos citar a fase futurista - a momentos de maior desatenção ou de debates restritos que englobam autores, obras e momentos isolados. Existem razões histórico-culturais que favoreceram tal marginalização crítica no Novecento italiano. A principal é a refutação do Positivismo exercida pelo idealismo de Benedetto Croce, filósofo que durante muito tempo moldou o debate acerca da literatura naquele país. Dessa forma, a relação ciência-literatura parece ter tido um papel marginal para a crítica italiana em comparação ao problema estilístico-literário: a análise do texto a partir da perspectiva do estilo, da linguagem e das relações histórico-sociais sempre esteve em primeiro plano e, no caso italiano, sufocou a análise de outras possíveis relações.

Acontece que, em alguns escritores, a cultura humanística-literária funde-se com a chamada cultura científica, fazendo com que seja impossível separar a ciência da literatura ou a literatura da ciência. $\mathrm{Na}$ Itália do período pós-Segunda Guerra, Italo Calvino, como crítico e ficcionista, tem um papel central na discussão literária: ele se apresenta como um autor que deu à literatura a função de instrumento de conhecimento e de "mapa do mundo", delineando contextualmente uma tipologia literária que reagrupa projetos e experiências de escritos heterogêneos, não vinculados a poéticas, a períodos ou a estilos 
particulares, mas a uma comum compreensão da literatura como forma do conhecimento do todo. A fórmula é proposta no artigo "Filosofia e literatura", que consiste em confrontar as várias modalidades cognitivas em um "ménage a trois":

A ciência está diante de problemas nada dessemelhantes
daqueles da literatura; constrói modelos do mundo que são
postos o tempo todo em crise, alterna método indutivo e
dedutivo, e sempre tem de ficar atenta para não tomar por
leis objetivas as próprias convenções linguísticas. Uma
cultura à altura da situação existirá apenas quando a
problemática da ciência, a da filosofia e a da literatura se
puserem continuamente em crise revezadamente.
(CALVINO, 2009, p. 185)

Recorrer ao "ménage a trois" proposto por Calvino evitaria a separação entre as "duas culturas" - literária e científica -, mas, além disso, faria com que a crítica soubesse discernir melhor qual a ligação entre ambas. Antonello (2009, p. 5) complementa, ressaltando que, em alguns casos, "não se trata de despejar acriticamente o saber científico na literatura, mas sim de fazer com que a literatura tome a ciência como modelo, como metodologia para narrar o mundo" e, assim, em alguns autores italianos, ciência e literatura aproximam-se, tornando-se intrínsecas. Do ponto de vista hermenêutico, a ciência e a técnica e devem ser postas no centro da obra de autores como Italo Calvino ${ }^{28}$ ou Primo Levi, e não podem ser consideradas um exercício ocasional ou analisadas segundo uma perspectiva simplesmente temática, afinal fazem parte da própria formação de base desses escritores. Em outros termos, a ciência e além dela, a técnica - sempre esteve e sempre estará presente neles, sendo um dos parâmetros para abordar e interpretar seus escritos.

${ }^{28}$ Primo Levi, no ensaio "Com a chave da ciência", publicado no jornal La Stampa, em 20 de setembro de 1985, um dia após a morte de Calvino, diz que o "amigo e companheiro de itinerário" é "um caso único na cena literária italiana, e tinha fome de ciência. Cultivava-a, alimentava-se dela como diletante culto e crítico, e com ela alimentava seus livros mais maduros. Para ele, natureza e ciência eram uma coisa só: a ciência como lente para enxergar melhor, como chave para penetrar, como código para entender a natureza”. (LEVI, 2016, p. 274) 
Considerando tal premissa, as intuições, metáforas, imagens e temas, os procedimentos da descoberta científica ou da literatura devem ser considerados transversalmente em relação às várias disciplinas do conhecimento. Portanto, a análise da relação entre ciência/técnica e literatura deve partir do pressuposto de que, mais do que se complementarem, em alguns autores elas são indissociáveis.

\section{Primo Levi: ciência, técnica e literatura}

Primo Levi é um dos mais significativos escritores europeus do segundo pós-guerra. Nascido em Turim, o químico de origem judaica é representante incontestável, um ícone da vertente de escritores/técnicos/cientistas na literatura italiana. A experiência como prisioneiro dos nazistas, durante a Segunda Guerra, em um dos campos de concentração do complexo de Auschwitz, dá origem a uma literatura que, primeiramente, apega-se à temática concentracionária, para depois se aventurar nos campos da fantasia e da ficção-científica. Levi é um autor poliédrico e complexo, responsável por uma literatura refinada que nasce exatamente da sua mente de químico, e se relaciona com a ciência que o formou e com o trabalho técnico no laboratório. A semelhante natureza das "duas culturas", que pareceu ter sido abandonada pela ciência moderna, encontra suas evidências nos escritos de autores como Primo Levi, afinal, como afirma Montesperelli (2006, p. 10), "a convergência entre o pensamento científico e a criação artística revela que uma mesma sensibilidade subentende os dois saberes, permitindo a passagem da ciência ao sonho e vice-versa". O mito iluminista/positivista da ciência absoluta e exclusivamente racional não encontra no decorrer do século XX sua afirmação.

A lógica, a precisão, a concisão e o descritivismo - características que podem ser associadas à escrita científica - fazem parte da linguagem de Levi de maneira determinante. $O$ trabalho técnico do químico, como veremos, é espelhado igualmente no trabalho técnico do escritor. Assim, para interpretar a sua literatura, não basta uma "exclusiva perspectiva estilístico-expressiva”. Antonello (2009, p. 3) nos dá essa dimensão, expondo que uma análise dos literatos chamados de "impuros", como é o caso de Levi, requer uma "adicionalidade hermenêutica contínua, no sentido de uma plena integração dos planos discursivos", fazendo convergir com as intenções do autor de "ampliar os pontos de vista a partir dos quais reconhecer, sondar e expressar a realidade”. Dessa forma, a literatura do químico de Turim não pode se dissociar da ciência, da 
técnica e, mais especificamente, da química. Todos esses fatores são fundamentais no processo interpretativo de sua obra.

Por isso, a crítica que tende a reduzir a complexidade e a depurar a ambiguidade de textos como aqueles de Levi, sem dar a devida atenção às suas várias possibilidades de leitura, tende também, em alguns casos, a demonstrar uma visão parcial ou falha das potencialidades que estão presentes em sua obra. Essa crítica - de caráter restritivo e limitador -, que considerava o autor dentro de seu papel de testemunha do Lager, e nada mais, parecia não considerar as várias linhas de força que vão além das estilístico-expressivas-documentais, pois ignoravam elementos essenciais à construção de sentido de suas obras: a ciência e a técnica. A "interpretação científico-tecnológica" parece oferecer nesses casos novas perspectivas linguísticas, expressivas e narrativas, em um vasto processo de ressignificação da palavra. Em Levi, por exemplo, a química oferece, além de um aparato lexical significativo, uma gama de possibilidades em seu processo criativo.

Irrefutavelmente, a literatura de Primo Levi é construída a partir da ciência e com a ciência. Para ele, o ato de escrever, de fazer literatura, era também um trabalho técnico, como aquele do químico. Ou seja, toda a literatura de Levi provém de uma mente acostumada a raciocinar segundo os parâmetros da ciência e, principalmente, de acordo com os pressupostos técnicos da química. Todos os seus escritos, inclusive a literatura de testemunho, têm a "cultura científica" como base, e neles podemos encontrá-la de maneira evidente. Levi se considerou durante algumas décadas - e por muitos foi considerado - "escritor por acaso". Seus escritos, pelo menos até o final da década de 70, eram tratados por muitos críticos como narrativas de um químico que sobreviveu aos campos de concentração e extermínio nazistas. Levi foi reconhecido como escritor relativamente tarde.

Mas, é importante destacar que, no caso de Levi, a ciência não é simples motivo temático, a partir do qual se possam pensar as crises e contradições da modernidade ou as benesses ou malefícios do progresso tecnológico e material. Para além dessa consideração, o pensamento científico deve ser um quadro de referência geral, tornando-se uma possível maneira de abordar, interpretar e explicar a realidade, assumindo assim o caráter de poética, estética e ética, por meio dos quais podemos analisar criticamente a literatura que aí se insere. Tanto Levi quanto Calvino eram movidos pela curiosidade, que neles tinha um caráter de paixão e desejo: paixão por observar, analisar, investigar; desejo por 
descobrir, compreender e revelar. Além disso, em Levi, a ciência é um de seus temas, mas é também uma potencialidade linguística, é conteúdo e é forma, é instrumento para compreender e conhecer.

Analisar os escritos de Levi evitando a sua aproximação com a ciência e, mais precisamente, com a química, ou ainda apenas tangenciando-as, seria incorrer em equívoco e desconhecer a complexidade de sua obra, já que a ciência e a técnica são partes integrantes e indissociáveis, tanto de sua literatura de testemunho quanto de sua literatura assumidamente ficcional. Assim, Levi participa da cultura italiana como um dos casos mais notáveis em que ciência e literatura coincidem, se retroalimentam e não se dissociam. Isso significa que a obra literária do autor apresenta uma fusão entre a cultura científica e a cultura humanística, fator que é consequência da confiança em um conhecimento amplo e irrestrito, feito de disciplinas convergentes, que são plenamente comunicáveis dentro de uma complexidade: sua literatura constrói a ponte que liga a linguagem científica à linguagem literária, fundamentando-se em um pensamento formado pela ciência, o que lhe confere uma infinidade de possibilidades estilísticas capazes de torná-lo um dos maiores representantes da literatura europeia do segundo pós-guerra.

\section{A formação científica e a gênese da literatura de Primo Levi}

A formação primeira de Primo Levi é científica: nascido em uma família na qual a cultura científica era extremamente valorizada, foi influenciado pelo pai, Cesare, a inclinar-se ao campo das ciências desde cedo. O pai, engenheiro eletrotécnico, pode ser considerado um dos principais responsáveis por dois fatos de suma importância na vida do filho: o primeiro, foi despertar no jovem o hábito da leitura, tão recorrente e comum no ambiente familiar, como o autor irá declarar por mais de uma vez; o segundo, contribuir decisivamente para a formação científica do jovem Primo Levi, presenteando-o com livros de divulgação científica, que suscitariam no adolescente a curiosidade e, posteriormente, a vontade de investigar, especular, demonstrar.

A base da cultura científica de Primo Levi é aquela, primeiramente, aprendida nos livros que o pai lhe presenteava e, depois, no liceu e nos ambientes da universidade, com ecos positivistas e deterministas. A princípio, cabe ressaltar que a cultura científica de Levi era profunda e vasta. Em seus diversos ensaios e entrevistas, quando fala a respeito da ciência e de tudo o que a envolve, conseguimos depreender de 
suas palavras conhecimentos que vão além da química, passando pela física, pela astronomia, pela biologia e pelas inovações tecnológicas de sua época e de épocas anteriores. Obviamente, a vasta cultura científica e a frequente busca por atualização de seus conhecimentos influenciam de maneira decisiva toda a sua obra literária. No que diz respeito aos contos de ficção-científica, o conhecimento que engloba as diversas disciplinas, somado a uma fértil capacidade criativa, é responsável por montar cenários futuros totalmente factíveis, baseados no desenvolvimento plausível da ciência, além de fazer daquelas narrativas modelos da tradicional ficção-científica, que se alia ao fantástico em muitas oportunidades. Além do mais, Levi concebia esse gênero da literatura, como "científico", pautado pela fantasia criadora, mas também baseado no conhecimento técnico-científico do autor.

O livro de estreia de Primo Levi, É isto um homem? (lançado pela primeira vez em 1947, pela pequena editora De Silva, e depois ampliado e reeditado pela editora Einaudi, em 1958), nasce da já tão comentada necessidade de narrar. Mas podemos considerar que a necessidade de narrar, por sua vez, está intrinsecamente ligada a uma outra necessidade: a de entender o porquê. Muito se discutiu sobre a capacidade de Levi narrar o inenarrável, na tentativa de compreender o incompreensível. Alguns críticos, que se debruçam sobre o tema do testemunho pósAuschwitz, pautam seus estudos e análises nos relatos e nas reflexões de Levi, que condiciona sua sobrevivência à necessidade de narrar sua experiência. $\mathrm{O}$ que pouco se discutiu até hoje é como essa necessidade de narrar e compreender nasce exatamente da mente científica e analítica do autor. E considerar a ciência como base de seus escritos é, de fato, a condição necessária para a leitura de toda sua obra.

A ciência era, portanto, fonte de conhecimento, mas, ao mesmo tempo, de paixões: fascinava-o, por exemplo, "o aspecto romântico da ciência presente na química” (LEVI; REGGE, 2005, p. 18), ciência formadora de seu pensamento. Levi concebia a ciência e a literatura como atividades semelhantes, construções que obedecem à lógica dos pequenos e pacientes passos: do ponto de vista técnico, o trabalho realizado no laboratório é semelhante, se não idêntico, àquele realizado pelo escritor. Porém, as duas atividades não se assemelhavam somente porque partiam e utilizavam o mesmo modus operandi. Ciência e literatura, em sua concepção, eram complementares e não se constituíam como campos do saber independentes, nem tampouco apenas relacionados: eram partes de um mesmo todo, intimamente interligadas e inseparáveis. 
A relação entre ciência e literatura parece, em Primo Levi, atingir outro patamar. Para nosso autor, ambas têm uma recíproca função cognitiva e uma comum metodologia em sua constituição. Levi é testemunha da possibilidade desse diálogo e da mútua construção, uma vez que, no seu caso, o químico ensinou muitas coisas ao escritor, tais como ser humilde, paciente, metódico, provar e reprovar disposições e fórmulas que façam com que uma página, ou um prédio, fiquem em pé. Levi afirma categoricamente que as barreiras disciplinares existentes entre ciência e literatura devem ser superadas:

Pode muito bem existir um escritor que ignora totalmente a ciência e a técnica, e ser um escritor respeitabilíssimo e válido. [...] Mas me parece que seria bom se o escritor não vivesse, não digo em uma torre de marfim, mas em um cano, em uma tubulação que parte de Dante e chega ao Infinito. E ele se move nessa tubulação sem nunca ver o mundo em torno de si. Se vivemos em um mundo repleto de tecnologia e de ciência, não é aconselhável ignorá-lo, mesmo porque a Ciência, com o $\mathrm{C}$ maiúsculo, e a Tecnologia, com o T maiúsculo, são formidáveis fontes de inspiração. [...] Parece-me ser uma cegueira involuntária esta. Significa perder a medida do universo no qual vivemos... O fato de as culturas serem duas já é, de início, nocivo. Deveria ser uma só [...]. (LEVI, 1997, pp. 173-174, tradução nossa) $)^{29}$

Assim, Levi torna-se escritor não em contraste com sua formação científica, mas sim porque é um químico. A sua natureza híbrida, que une as "duas culturas" nasce de uma educação humanística da escola média, mas também das leituras no ambiente familiar, que lhe proporcionaram o contato com autores clássicos, às vezes muito diversos entre si: Dante, Leopardi, autores judaicos, moralistas, poetas dialetais, escritores de aventura e, enfim, cientistas. O Primo Levi escritor constrói-se a partir da junção de alguns elementos: a sua educação humanística, adquirida em

${ }^{29}$ Todas as citações do presente artigo estão em língua portuguesa. As citações de obras que contam com uma edição brasileira, reproduzem a respectiva tradução. As que não têm uma edição em português, estão indicadas como "tradução nossa". 
casa e ao longo de sua formação, principalmente nos anos do liceu; a sua condição de ex-deportado e sobrevivente, responsável por sua literatura de testemunho, a qual representa a gênese de sua carreira como escritor; e, por fim, o seu trabalho como químico, que influencia de forma extremamente relevante todos os seus escritos, e também está na gênese de sua literatura. É exatamente "dessas três experiências que deriva uma quarta, que se sobrepõe às outras três, e termina por assumir em sua vida o papel mais importante: o escrever.

Auschwitz é, sem dúvida, o evento decisivo de sua vida. Poderíamos, inclusive, como muito se fez ao longo da carreira de Levi, e mesmo após a sua morte, questionar se sem Auschwitz existiria o escritor. Essa é, porém, uma questão sem resposta.

A pergunta que os meus leitores do ensino médio frequentemente fazem ('Se o senhor não tivesse estado no Lager e não tivesse estudado química, teria escrito mesmo assim? E, se sim, da mesma forma?'), só poderia ter uma resposta sensata se houvesse um outro Primo Levi, que não tivesse estudado química e tivesse começado a escrever. A contraprova não existe. (LEVI, 2018, p. 118, tradução nossa)

Levi muitas vezes declarou que somente se tornou um "verdadeiro homem" depois de dois fatos fundamentais na sua vida: a deportação e a liberação interior por meio do testemunho, da escrita. Em outras ocasiões, ele ainda afirmou que o Lager foi sua segunda universidade, e que sua vida, antes monótona e carente de aventuras, ganhou um novo sentido após a deportação e a liberação. Cita um amigo médico que teria dito ao autor (ROTH, 2004, p. 12): "as suas recordações de antes e depois são em branco em preto; aquelas de Auschwitz e do retorno para casa são em technicolor". Por esse motivo, a epistemologia de Levi, no retorno de Auschwitz, não pode ser a mesma do estudante ou do químico recémformado.

O ofício de químico é responsável por "fornecer a matéria-prima" ao seu trabalho de escritor, "bem como a própria forma de contar". Ou seja, "o gosto pelo concreto, pelo definido, pela palavra exata usada para comunicar-se" com clareza, precisão e concisão, "vem da sua formação técnico-científica" (CALCAGNO; POLI, 2013, p. 71). Levi define a si mesmo como um "centauro": químico e escritor; italiano e judeu; 
deportado e sobrevivente. Também se coloca como escritor de “domingo", ao menos até 1975, quando se aposenta da indústria na qual trabalhava como químico.

O "ménage a trois" proposto por Italo Calvino, do qual faziam parte a literatura, a ciência e a filosofia, é invocado também por Levi. Porém, no "ménage a trois" primoleviano, a filosofia é substituída pela técnica, representada pelo mundo do trabalho ${ }^{30}$. Assim, em suas obras, podemos considerar a tríade ciência, literatura e técnica que, segundo Antonello (2009, p. 82) "constituem uma espécie de pedagogia do material em oposição ao idealismo": Levi apresenta a significativa e peculiar capacidade de conjugar literatura, ciência, técnica; arte, conhecimento e trabalho manual; capacidade natural de se servir de todas as lentes das quais o estudo, a cultura, a formação, a curiosidade, as leituras dotaramno.

A ciência, na literatura de Levi, é o filtro através do qual ele observa a realidade a seu redor; seu pensamento científico é um fator determinante - e talvez o mais determinante deles - para a construção de sua literatura. Sem tal perspectiva científica, o deportado Primo Levi não seria o mesmo observador que está na gênese da construção de sua primeira obra. Dessa forma, não seria exagero afirmar que $\dot{E}$ isto um homem? existe - da forma que é - somente devido a esse fator. Porém, a ciência é também, além de tema e ponto de vista a partir do qual parte a sua obra, ponto de reflexão. A reflexão sobre o próprio fazer científico está presente - de forma clara, às vezes irônica, sarcástica - nos contos de ficção-científica que nasceram logo no início de sua carreira como escritor, paralelamente à literatura de testemunho, e que se articulam intimamente com a reflexão sobre a condição humana, esse sim o tema central de toda a literatura de Levi.

${ }^{30}$ Os problemas filosóficos, segundo Levi, são sempre os mesmos desde os pré-socráticos e, diferentemente dos problemas científicos, não chegam a uma conclusão ou solução concreta: "[...] estou habituado a uma vida concreta, na qual o problema ou se resolve, ou se joga fora. Os problemas filosóficos, ao contrário, são sempre aqueles dos pré-socráticos [...] E, além disso, cada filósofo tem o vício de inventar a própria linguagem, que gera a necessidade de se esforçar para penetrá-la, antes de entender o que quer dizer. Não é para mim...”. (In: Conversazioni e interviste, p. 204, tradução nossa) 
A ciência e a técnica, na perspectiva do autor, têm um caráter ambivalente, no qual as duas faces têm que ser consideradas: se, por um lado, podem transformar positivamente a realidade, portando equilíbrio, por outro, podem ser responsáveis por transformações capazes de levar a humanidade e o planeta ao caos. O naufrágio do intelecto, entendido como uso irracional da ciência e da técnica, que pode levar à catástrofe e à desordem, bem como à desumanização, é objetivamente possível. Em seus contos de ficção científica ${ }^{31}$, por exemplo, não observamos esperança ou possibilidade de resgate do humano naquele mundo hiperdisciplinado, caótico e assustador. Mas, mesmo assim, Levi não parece querer demonstrar uma conclusão definitiva, já que o caráter de alerta de seus escritos, por assim dizer, apocalípticos tem a intenção de recordar que "a razão pode também ser a 'mãe do nada', ou que o Lager pode ser o seu produto”. (DI MEO, 2011, p. 60)

Percebemos que, nos últimos anos, a análise da obra de Primo Levi pela crítica italiana considera-a de modo sincrônico, estabelecendo em seu âmbito geral uma evolução intelectual, tanto em sentido literário, quanto em sentido propriamente científico. Não há dúvidas de que a sua obra estabelece uma passagem da concepção positivista e determinista do universo a uma concepção ligada à complexidade, no que se refere à ciência, ao humano e aos processos históricos. Tal dinâmica se reflete em sua escrita, em seus temas e nas figuras tratadas, e no modo como ele renovou continuamente sua literatura e sua análise da história do século XX.

A literatura de Levi obedece à curiosidade 'cínica' do naturalista que pode olhar para o Lager como um laboratório de ciências humanas. Aqui, "o termo naturalismo indica a adoção na literatura, como em Zola, de um protocolo experimental na observação e compreensão do real. Mas, ainda mais,

o termo assinala um caráter 'etológico' de investigação sobre a natureza humana, reconduzida às suas raízes

31 Os contos de ficção-científica de Primo Levi foram lançados pela editora Einaudi em 1966, na coletânea Histórias naturais. Em 1971, a editora lançaria a segunda coletânea: Vício de forma. A maioria dos contos presentes nas duas obras já havia sido apresentada ao público em diversos periódicos ou jornais. 
animais e biológicas. $\mathrm{O}$ naturalismo é a adoção de uma metodologia da observação, modelada sobre procedimentos de laboratório: assim se explica por que um texto como Os afogados e os sobreviventes pode mover uma epistemologia da observação (PORRO, 1997, p. 438).

Às suas narrativas e reflexões sobre o Lager e sobre a ciência, que formam o início de seu itinerário como escritor, (os testemunhos $E$ isto um homem? e A trégua; os contos de Histórias naturais e Vício de forma) agregam-se outros gêneros literários capazes de demonstrar outras vias de expressão, como o romance de formação (A tabela periódica), os contos etnológicos sobre o trabalho (A chave estrela) ou o romance histórico (Se não agora, quando?). A obra de Levi não é, portanto, um "monólito" que trata somente da memorialística do campo de concentração.

Em todo esse itinerário, a par do escritor que busca por um estilo que o identifique e dê credibilidade à sua literatura, está o químico, que analisa o campo de concentração com os olhos do cientista, e registra em suas páginas um relato detalhado daquele "gigantesco experimento biológico e social". Nesse contexto, a química, enquanto ciência e trabalho técnico, constitui em Primo Levi parte essencial e fundamental. É o filtro que permite ao autor o desenvolvimento de sua visão de mundo e de sua literatura, influenciando o seu modo de narrar, a escrita concisa e pretensamente clara por ele cultivada.

\section{A química como instrumento e metáfora da criação literária}

O interesse de Primo Levi pela química nasceu por volta dos 14 anos de idade, enquanto cursava o liceu clássico "Massimo D’Azeglio", célebre escola de Turim. Na Itália, durante muito tempo, as famílias tinham a opção de matricular seus filhos em dois tipos de liceu, o clássico e o científico, mas, para as famílias burguesas de Turim, como a de Levi, a cultura clássica tradicional sempre teve um papel de fundamental importância e, por isso, para os filhos dessas famílias tradicionalistas, era praticamente inconcebível uma educação que não passasse pelo liceu clássico. Isso, até mesmo para a sua família, formada por duas gerações anteriores de engenheiros. Levi era um leitor ávido, hábito que, mais que incentivado pela família, fazia parte do seu cotidiano. Lia desde a literatura clássica e contemporânea até textos científicos. 
O autor é filho de uma época de reformas fascistas na educação ${ }^{32}$, que provocaram significativas mudanças e, dentre elas, o fato de que a cultura científica é deixada de lado em favor de uma cultura humanística e literária. A separação hierárquica das "duas culturas" ${ }^{33}$, promovida pelas reformas fascistas, contribui para suscitar ainda mais a curiosidade de Levi, que se recorda da frase de uma professora de italiano: "as matérias literárias eram formativas, enquanto as científicas tinham um caráter meramente informativo". Levi decidia então, inspirado por uma atmosfera antifascista, proporcionada por alguns professores, e pela curiosidade que sempre foi marca de sua personalidade, que a sua chave de leitura do mundo não seria aquela literária, e sim a científica, e que a

${ }^{32}$ Cf. DE GRAZIA, V.; LUZZATO, S. Dizionario del Fascismo. Torino: Einaudi, 2005, vol. 2, pp. 511-514. As reformas na educação durante o fascismo foram implementadas no ano escolástico 1923-1924. O eco da Primeira Guerra Mundial conferiu ao projeto de reforma um caráter decisivamente nacionalista, que fazia parte de um "desenho político mais vasto que via na reorganização da escola o necessário pressuposto para a renovação espiritual e ética da Itália, e que visava à criação de um estado nacional forte”. Basicamente, a reforma constituía em uma reestruturação do ensino básico, dando destaque às matérias humanísticas. Em uma perspectiva idealista, privilegiava-se o estudo, por exemplo, das línguas antigas em detrimento das disciplinas científicas. "Um sistema de controles formalizados do rendimento e de mecanismos seletivos, devia garantir ao liceu clássico o status de lugar de formação das classes superiores". A reforma visava à restauração dos privilégios, no campo escolástico, de uma elite burguesa, a qual o status vinha sendo tutelado através de um complexo sistema seletivo que deveria servir como uma barreira social, ou seja, impedir que as massas - a base social do próprio fascismo - atingissem a educação que era dispensada à burguesia. A consequência foi um esvaziamento da escola secundária.

33 A educação fascista dava preferência às matérias ditas humanísticas, deixando em segundo plano, aquelas "científicas". Ao escolher a química, Primo Levi estabelece uma espécie de desafio a essa preferência, uma escolha que ia de encontro às ferramentas ideológicas da retórica fascista. Ao escolher uma ciência exata, na qual os resultados são comprobatórios de experiências reais e concretas, Levi afasta-se da ideia difundida pelas reformas educacionais do fascismo, que hierarquizava as disciplinas e colocava aquelas humanísticas como superiores às cientificas. 
análise da matéria, e não da poesia, seria a estrada a ser percorrida para desvendar os segredos do universo.

Aquela espécie de proibição soou como um desafio ao estudante já apaixonado pelas disciplinas científicas, assim como soaria a qualquer adolescente curioso e explorador. A química tornava-se para Levi (2011, pp. 121-127) um estimulante, uma ciência natural de caráter limpo e que poderia servir como um "antídoto para a insistência do regime fascista nas ciências humanas e em sua propaganda política"; uma ciência "clara e distinta, a cada passo verificável, não composta de mentiras", como poderiam ser as humanidades, ligadas à propaganda fascista ou intencionalmente povoadas por ela: a literatura, a filosofia, a história, por exemplo, eram disciplinas que poderiam ser, potencialmente, distorcidas ou invadidas pela retórica e pela ideologia fascista. Para Levi, "a química é uma alegoria da vida, é a luta contra as mistificações do fascismo": a ciência do pesar, dividir, destilar e retificar, que mais tarde iria influenciar sua escrita clara e concisa. Levi, em sua escrita, "pesa as palavras, objetivando a precisão, a comunicação eficaz", seguindo por outros meios, através da literatura, os preceitos da ciência, ou seja, "a ordenação e explicação do real”. (PORRO, 2009, p. 133)

A química, elemento que liga as diversas experiências narrativas do autor, do cronista do Lager ao escritor de ficção, é também a chave para a compreensão de sua obra literária, sem a qual não se pode interpretar plenamente seu conteúdo e estilo; é o próprio elo entre ciência e literatura; é a ferramenta para explicar o mundo, a natureza, suas riquezas e a própria vida; é fator onipresente em sua obra, sendo responsável, por oferecer subsídios para a descrição da realidade geral do homem e da natureza, bem como da relação entre eles. Configurava-se, naquele momento da juventude no liceu, como uma espécie de contínua experimentação da "verdade molecular" contra "o fedor das verdades fascistas que infestavam o céu": existiam experimentos, demonstrações, provas, que não as deixavam mentir. A química tinha "qualquer coisa de mágico"; era, na visão do jovem estudante, o caminho para descobrir "os segredos do céu e da Terra", "um dos grandes poderes do homem", capaz de fazê-lo entender "o porquê das coisas" (LEVI; REGGE, 2005, p. 14). O jovem havia se interessado por certo caráter romântico presente na química:

[...] escolhi interessar-me pela química quando era um menino, tinha 14-15 anos: [...] e a química me parecia a 
principal chave para abrir os segredos do céu e da terra, e ter lido então, que um espectroscópio permitia conhecer a composição química de uma estrela, parecia-me um dos máximos poderes do homem (CAMON, 1997, pp. 69-70, tradução nossa).

A clareza, tão cultivada por Levi em sua escrita, é a característica mais atraente que o jovem estudante de liceu encontra na ciência que determinará o rumo de sua vida, de seu trabalho e de sua arte. A sua escolha nada mais é do que a expressão de uma preliminar confiança na ciência em oposição às matérias humanísticas, então carregadas do idealismo fascista.

A química [...] interiormente, creio que me tenha ensinado também a escrever, de certo modo. Tenho pensado que o meu modelo literário não é nem Petrarca, nem Goethe, mas o pequeno relatório de fim de semana, aquele que se faz na fábrica ou no laboratório, e que deve ser claro e conciso, e pouco conceder àquilo que se chama de 'escrever bonito'. [...] Sinto a tarefa de escrever como um serviço público que deve funcionar: o leitor deve entender o que escrevo, não digo todos os leitores, mas a maior parte dos leitores, mesmo se não forem muito preparados, devem receber a minha comunicação, não digo mensagem, mas a minha comunicação. O livro escrito deve ser um telefone que funciona; e acredito que a química me tenha ensinado esses dois dotes da clareza e da concisão (LEVI, 1997, p. 40, tradução nossa).

A escolha decisiva da vida do autor, como observamos, é fruto da ânsia pelo conhecimento, pela exatidão e pela clareza, em oposição à névoa provocada pela ideologia fascista. Mas é, ao mesmo tempo, fruto do aspecto mágico e misterioso dessa ciência que tem origem na alquimia. A convicção antifascista de Levi, que é um dos fatores que o inclinavam às disciplinas científicas, é alimentada e fortalecida, certamente, pela exclusão determinada pelas leis raciais do fascismo na Itália: a exclusão por pertencer a uma etnia diversa daquela considerada "superior", inaugura um caminho em direção ao conhecimento. Levi diz que nos anos de liceu nunca sofreu agressões físicas ou insultos diretamente, mas 
inegavelmente era ironizado por ser judeu e por colocarem em dúvida sua sexualidade (CAMON, 1997, p. 70).

Levi ingressa na universidade em 1937, envolvido pela atmosfera antissemita que era propagada, inclusive, pelos meios de comunicação. Em 1938, as leis raciais começam a tomar corpo e determinam, entre outras coisas, que os judeus estrangeiros seriam expulsos da Itália, enquanto aos judeus italianos uma série de restrições seriam impostas: a cessão do direito de frequentar escolas públicas - seja como alunos, seja como professores -, a proibição de trabalhar nos escritórios públicos ou de servir o exército, a restrição de valor de propriedades ou de salários, a proibição de se casar com não-judeus etc. No caso de Levi, porém, as leis não determinaram a interrupção do curso de química, uma vez que não se aplicavam àqueles judeus que já se encontravam no decorrer de seus estudos na universidade. Para ele e para outros colegas de curso, as leis não interferiram, na prática, na conclusão de seus estudos, mas tiveram um efeito psicológico muito significativo: um judeu, apesar de poder terminar o curso que havia começado, não poderia prolongá-lo, o que significava não poder perder nenhum exame.

Nos anos de universidade - uma universidade também antifascista em sua maioria - Levi teve um convívio pacífico com os colegas de curso: nenhuma declaração do autor dá conta de que tenha sofrido preconceito ou insultos por sua origem. Pelo contrário, os colegas tentavam amenizar a separação provocada na universidade pelas leis raciais e suas biografias destacam o quanto ele era respeitado. A ele recorriam, às vezes, para determinados conselhos ou esclarecimentos. Levi gradua-se com nota máxima e louvor, e obtém o diploma de graduação que traz uma ressalva: "de raça hebraica".

A universidade é responsável, enfim, por colocar o jovem que escolhera a química por convicção em contato com o trabalho prático que envolvia aquela ciência. Finalmente o estudante entra em contato com a matéria nos laboratórios, observando a prática cotidiana daquele trabalho que exigia paciência, meticulosidade, esmero e objetividade. $\mathrm{O}$ primeiro contato de Levi com a prática da química havia acontecido nos anos do liceu, no laboratório improvisado do irmão mais velho do amigo Mario Piacenza (história contada em "Hidrogênio", o segundo conto de A tabela periódica); na universidade, o contato mais direto e frequente molda o pensamento do técnico: é no contato com a matéria, "mãe e inimiga", que o intuito de ordenar o caos, de tornar tudo o mais claro possível, 
objetivando a compreensão, transforma-se em ponto crucial de seus dois ofícios.

A química de Levi é a química "da medida do homem", "solitária, desamparada e desmontada"; aproxima-se da matéria dos antigos alquimistas, preocupada com as descobertas individuais, no contato direto e pessoal, quase uma "cozinha":

[...] a minha química, que era uma química "baixa", quase uma cozinha, me forneceu, em primeiro lugar, uma vasta variedade de metáforas. Vejo-me mais rico do que outros colegas escritores, porque, para mim, termos como 'claro', 'escuro', 'pesado', 'leve', 'azul' têm uma gama de significados mais extensa e concreta. [...] Quero dizer que tive nas mãos materiais de uso não corrente, com propriedades fora do comum, que serviram para ampliar exatamente o sentido técnico da minha linguagem. Disponho, então, de um inventário de matérias-primas, um pouco mais vasto do que aquele que não tem uma formação técnica. No mais, desenvolvi o hábito da escrita breve, de evitar o supérfluo (LEVI; REGGE, 2005, p. 59, tradução nossa).

Da preocupação inicial em separar o químico do escritor, nos anos iniciais de sua carreira literária, apresentando-se como um "anfíbio, um centauro", Levi chega à concepção de que não há uma separação entre essas suas duas naturezas. A partir de um determinado momento, não se preocupou mais em distinguir claramente e separar sua atividade de escritor da profissão de químico. Ao contrário disso, sempre fez questão de destacar quão grande foi a contribuição de sua formação profissional em sua literatura: a química foi a responsável por criar um escritor paciente e preciso; por uma literatura igualmente clara e coesa, propensa a evitar o supérfluo, e habituada à objetividade, realizada para esclarecer, levar à compreensão, ao entendimento:

Existem outros benefícios, outros dons que o químico cede ao escritor. O hábito de penetrar na matéria, querer saber a sua composição e estrutura, prever suas propriedades e seu comportamento, conduz a um insight, a um hábito mental de concretude e de concisão, ao desejo constante de não se 
limitar à superfície das coisas. A química è a arte de separar, pesar e distinguir: são exercícios úteis inclusive para quem se propõe a descrever fatos e dar corpo à própria fantasia (LEVI, 2011, p. 13, tradução nossa).

O "separar", "pesar" e "destilar" a matéria transferem-se para a literatura através da experiência, que é a matéria-prima de sua narrativa. O escritor, partindo de sua experiência como deportado e como técnico, "separa", "pesa" e "destila" aquilo que se transformará em literatura formada a partir da constituição de um processo de formação e montagem que, nele, é analítica e ponderada (BARTEZZAGHI, 2012, p. 23): "a escolha daquilo que será narrado, a análise da realidade, não precede a escritura, mas é parte de seu processo de composição".

Levi (2011, pp. 14-15) afirma ainda que ele, enquanto escritor, pode retirar da química "um patrimônio imenso de metáforas" que só um escritor que frequentou o laboratório e a fábrica é capaz de explorar a fundo. Expressões como "preto como..."; "amargo como..."; "viscoso, fluido, volátil, inerte, inflamável" são características que um químico conhece muito mais. No já citado diálogo com Túlio Regge, Levi diz (2005, p. 60-61) que "para ele, ex químico, dizer 'filtrar' quer dizer alguma coisa a mais do que diz a quem é um laico", isto é, a alguém que não teve familiaridade com o trabalho técnico no laboratório.

Não há uma separação clara, na identidade "centauresca" de Levi, entre o químico, o deportado, o sobrevivente e o escritor. Assim, o cientista está presente no escritor e o escritor, mesmo que de forma tímida ou "adormecida", estava presente no químico. O intercâmbio e a integração constante, em sua formação, entre a cultura humanística e a cultura científica ratificam sua posição, que nega peremptoriamente uma separação entre as duas culturas, afirmando a existência de um só universo cultural, que integra os diversos campos do conhecimento. Levi diria (2011, p. 14): "quando um leitor se espanta pelo fato de que eu, químico, tenha escolhido o caminho da literatura, sinto-me autorizado a responder que escrevo exatamente porque sou um químico".

Marco Belpoliti (2005, p. VI), crítico e organizador das obras completas do autor, afirma que Levi "já era escritor" mesmo antes da deportação: "os companheiros de universidade recordam que o autor tinha a intenção de escrever um conto que tivesse como argumento principal um átomo de carbono”. Essa história, que seria depois publicada em A tabela periódica, é aquela que fecha o livro, "Carbono", e 
foi contada por ele aos colegas, naqueles anos, de forma resumida. Aliás, vale dizer que muitos dos contos de Levi nascem dessa prática oral, sobretudo os relatos que formam A trégua, que, à sua maneira, não deixa de ser um livro de pequenos contos.

O olhar do químico deixa marcas profundas na obra literária, que interessa, inclusive, aos intelectuais do mundo das ciências exatas, no qual tem grande repercussão alguns de seus livros, sendo admirado pela capacidade de expressar seu amor pela profissão e pela ciência, por fazer saltar aos olhos as dimensões de aproximação da ciência à realidade e à vida. Os termos químicos em Levi expressam seu real significado, quando se referem à sua literatura: o "transformar-se em escritor" passa pela narrativa oral de sua experiência no Lager às pessoas mais próximas, e as histórias, repetidas várias vezes aos interlocutores, estavam, segundo ele, "cristalizando-se em uma forma definitiva, constante ${ }^{34 " ; ~ f a l a ~ d a ~ p o e s i a ~}$ como de "uma essência linguística que os poetas souberam destilar" (LEVI, 2011, pp. 20-22). "Destilar”, para Levi é, acima de tudo, quando se refere à literatura, produzir um texto essencial a partir da matéria-prima da experiência. A propósito, quando tratamos de Primo Levi, devemos sempre pensar em um escritor que zela pela exatidão dos significados dos termos utilizados, e que busca nas raízes etimológicas desses termos a justificativa para utilizá-los.

Destilar è bonito. Antes de tudo, porque é um ofício lento, filosófico e silencioso [...]. Mas ainda, porque comporta uma metamorfose: de líquido a vapor (invisível), e deste novamente a líquido; mas neste caminho duplo, para cima e para baixo, atinge-se a pureza, condição ambígua e fascinante, que parte da química e vai muito longe. E, finalmente, quando te propões a destilar, adquires a consciência de repetir um rito já consagrado pelos séculos, quase um ato religioso em que a partir de uma matéria imperfeita obténs a essência, o usía, o espírito e, em primeiro lugar, o álcool, que alegra o ânimo e aquece o coração (LEVI, 2001, p. 62).

${ }^{34}$ Introdução à versão dramática de Se questo è un uomo. In: Opere I, p. 1159.

35“La luna e noi”. In: L'altrui mestiere, pp. 20-22. 
Assim como na química, cujo objetivo é a clareza e a objetividade das composições, obtidas através de um trabalho minucioso, paciente e metódico, o "imperativo ético do escritor", segundo Levi, também se constitui dessa forma: a "clareza", termo sempre invocado pelo autor, é parte integrante de seu objetivo estilístico e ético, que ele afirma ter obtido do modelo da escritura científica, ou ainda, mais precisamente, do ofício de técnico que desempenhava no laboratório da SIVA, indústria na qual trabalhou no desenvolvimento de vernizes. Levi costumava afirmar que seu modelo de escrita é o do "relatório que se faz aos finais de semana na fábrica: claro, essencial e compreensível a todos":

[...] renunciando enfaticamente a qualquer pretensão normativa, proibitiva ou punitiva, gostaria de acrescentar que, a meu ver, não se deveria escrever de maneira obscura, porque um escrito tem muito mais valor [...], quanto melhor è compreendido e quanto menos se presta a interpretações equivocadas ${ }^{36}$. (LEVI, 2011, p. 49, tradução nossa)

Ou seja: para que haja comunicação deve haver clareza; para descrever a desordem de nosso tempo, o escritor não é obrigado a recorrer à desordem: descrever o caos no qual vivemos não significa transportar esse caos para a linguagem, como se ela fosse expressão do caos do mundo real. Para Levi, que se preocupou frequentemente em pôr ordem na desordem, em trazer a ordem em lugar do caos, a linguagem clara e precisa é uma das responsáveis para que se atinja esse objetivo, pois é capaz de sistematizar a realidade através de sua narrativa.

Apesar da linguagem de Levi prezar pela clareza, e de o autor relativamente atingir tal objetivo, no cerne de sua literatura está a Shoah, evento insondável e inexplicável, o que faz dele um daqueles escritores dos quais jamais conseguimos tocar o fundo: a pretensa clareza de seu estilo não é capaz de explicar completamente, e esgotar, um dos eventos

36 "Dello scrivere oscuro". In: L'altrui mestiere, pp. 49-55. Este artigo gerou uma grande e famosa polêmica com o escritor Giorgio Manganelli, acerca do escrever com clareza ou não. $\mathrm{O}$ artigo de Manganelli que polemiza com o de Levi se chama "Elogio dello scrivere oscuro", publicado no Corriere della sera de 3 de fevereiro de 1977. 
mais obscuros e inexplicáveis da história da humanidade. O Lager é, em Levi, matéria de sua literatura, argumento fundamental, pois antes de divagar sobre o significado daquele evento, o autor procura demonstrar, através do itinerário de sua obra, como aquilo tudo funcionava: ou seja, antes de saber o "porquê", é oportuno descrever o "como" tudo aquilo aconteceu. Dessa forma, o ponto de partida da literatura primoleviana, isto é, sua matéria-prima, é concreta, porque a experiência foi concreta. Levi não parte de um conceito, de uma ideia ou de uma imagem, mas sim de um evento, de fatos presenciados ou a ele narrados, mas, sobretudo, existentes, palpáveis, verificáveis.

Podemos considerar também que a divulgação científica, sobretudo aquela ligada à ciência de sua formação, foi um aspecto e uma ambição não secundária da literatura de Levi. Ele sente o leitor ao seu lado - "este leitor que tenho a curiosa impressão de ter ao meu lado quando escrevo" - e deseja que ele entenda aquilo que a sua literatura quer transmitir: "o meu leitor perfeito não é um Doto, mas também não é um inexperiente; [...] é curioso de muitas coisas [...]: de fato, escrevo para ele”. (LEVI, 2011, p. 53)

Dentre os vários aspectos de sua obra, que nasce da necessidade de narrar os eventos do Lager, podemos observar aquele que se propõe a divulgar a importância e o fascínio da ciência e da técnica, as suas relações, os resultados positivos e negativos desta relação. Como um primeiro exemplo dessa vertente, citamos A tabela periódica (1975). Coletânea de vinte e um contos, cada qual intitulado por um elemento da tabela periódica de Mendeleiev, o livro foi aclamado pela comunidade científica internacional como uma das maiores obras de divulgação científica da história, tendo recebido, em 2006, o prêmio de "melhor livro popular de conteúdo científico de todos os tempos” da prestigiosa Royal Institution of Great Britain ${ }^{37}$. Inicialmente, como declara o autor, seria um livro sobre "as aventuras dos químicos" ou um livro "sobre a química". Mas o que observamos, apesar de ser o texto do autor que mais

37 Figuravam na lista de concorrentes nomes de cientistas e escritores, como os dos biólogos Richard Dawkins, Jared Diamond e Peter Medaward; e dos escritores Konrad Lorenz, Bertolt Brecht e Primo Levi. Il sistema periodico foi escolhido como o melhor livro científico escrito até então, e seu último capítulo, "Carbono", foi selecionado como o melhor texto de literatura científica de todos os tempos. 
abertamente trata da química, é que A tabela periódica é, acima de tudo, um livro sobre "um químico", com a vocação latente de Primo Levi de contar a própria vida. As histórias ali reunidas são exemplos ilustrativos sobre sua relação com a química e com a vida e, de maneira mais geral, do homem com o seu trabalho.

A veia que constitui o caráter de divulgação científica na obra de Levi está também em alguns de seus numerosos ensaios, dentre os quais podemos citar "A assimetria e a vida", originalmente publicado na revista Prometeo (1984), que trata de maneira didática das moléculas chamadas "quirais", ou seja, aquelas que não se sobrepõem à própria imagem especular, característica, por exemplo, de alguns aminoácidos que estão na base da formação das proteínas. $\mathrm{O}$ autor, ao tratar de tais moléculas, tem a intenção de indagar sobre algo mais amplo e universal: o universo teria uma origem assimétrica? Esse tema, aliás, já tinha feito parte de sua tese de graduação sobre as Inversões de Walden (1941). Nos dois exemplos citados, assim como em outros ensaios e artigos escritos para jornais, percebemos que a intenção de Levi não é escrever sobre o que acontece dentro dos limites do laboratório, ou simplesmente falar sobre química. Mais do que isso, a sua intenção era expandir esse horizonte, para que o leitor pudesse conhecer a visão de um químico - ou da química - a respeito de sua vida e do mundo que o cerca.

\section{A tabela periódica}

Os anos de 1970 marcam uma mudança definitiva na vida de Primo Levi. Após 25 anos trabalhando na SIVA, uma indústria de vernizes, Levi começa a dar indícios de que desejava se aposentar e dedicar-se exclusivamente à literatura. Esgotado pela rotina da fábrica, "o agoniavam as responsabilidades burocráticas do cargo como diretor e, devido a diversos fatores pessoais, que envolviam problemas de relacionamento com os seus pares, já não tinha mais o mesmo prazer no antigo trabalho no laboratório de química" (THOMSON, 2007, p. 443). Além disso, o sucesso de suas obras anteriores, sobretudo A trégua vencedora do prêmio Campiello -, o encorajava a percorrer esse caminho, e a dedicar-se exclusivamente à sua atividade como escritor, tratando de maneira mais cuidadosa dessa outra parte do "centauro", que assumira ser durante a década de 60. A gênese de A tabela periódica é pois o desejo de falar sobre o ofício de químico e sobre a química. Em entrevista de 1963, Levi afirma: 
Sabemos tudo sobre mineiros, sobre ladrões, sobre rapazes da vida, sobre prostitutas, mas sobre químicos sabemos pouquíssimo: ninguém nunca se ocupou disto. Além disso, a arte do químico tem ideias e estímulos que mereceriam ser conhecidos... Tenho a tentação de escrever alguns contos sobre o meu ofício ${ }^{38}$.

Pressupõe-se, por intermédio de suas declarações, a utilização de uma veia fantástica, ficcional, para narrar, em um tom épico-picaresco, as experiências e as aventuras de um químico, obviamente representante de toda uma classe. Porém, o autor direciona-se a outro caminho, como veremos, partindo das próprias experiências que estavam ligadas à sua atividade como técnico.

A partir do final da década de 60, Levi começa a dedicar-se à composição de uma obra que iria representar a consolidação não só de sua carreira como escritor, mas que, anos mais tarde, seria responsável, também, pela sua consolidação, tanto na Itália quanto no exterior, como um dos principais escritores da literatura do pós-guerra. Em um trabalho de investigação, sobretudo em periódicos italianos e a partir das obras completas organizadas por Marco Belpoliti, sabemos que algumas histórias presentes em A tabela periódica (1975) já existiam no final da década de 60, mesmo algumas não sendo em suas versões definitivas. É o caso de "Titânio", que apareceu pela primeira vez com o título "Maria e o círculo", em L'Italia socialista (19 de setembro de 1948), e foi revisto pelo autor de modo que entrasse o elemento químico titânio, e se enquadrasse na obra que tinha como mote a tabela periódica dos elementos.

"Enxofre" é outro conto do final da década de 40: apareceu pela primeira vez com o título "Turno da noite", em L'Unità (31 de agosto de 1950), e também foi modificado para fazer parte do livro: a substância química citada na primeira versão não é o enxofre, e sim o bicarbonato, que não é um elemento presente na tabela periódica. $O$ conto é basicamente a narrativa de um dia de trabalho de um operário em uma fábrica, levando em consideração os procedimentos técnicos de produção de uma determinada substância. Os dois contos mais antigos do livro, datados do final dos anos 40 e início dos anos 50, apresentam um tom

38 "È tatuato sul braccio con un numero di cinque cifre". In: Paese sera, 12/07/1963. Entrevista de Primo Levi a Adolfo Chiesa, tradução nossa. 
narrativo diverso, uma vez que "Titânio" tem um tom de fábula e "Enxofre" um tom quase neorrealista, comum na literatura italiana daquele período.

"Carbono" foi publicado pela primeira vez na revista Uomini e libri, em 1972, e "Ouro" apareceu em Il Mondo em 18 de julho de 1974. Na apresentação redacional de "Carbono", datado de 1970, o autor destaca que a narrativa fazia parte de uma nova coletânea de contos, na qual estava trabalhando e indica como referência temática a veia narrativa de onde surgiram as coletâneas precedentes, Histórias naturais e Vício de forma. E, de fato, a história do átomo de carbono, já idealizada, segundo o Levi, durante a prisão em Aosta - que ocorreu antes da deportação para o campo de Auschwitz -, apresenta a nuance fantástica apresentada nos dois livros anteriores. A narrativa inicia-se, na versão definitiva, com uma espécie de conclusão ou explicação sobre o que representam todas as narrativas reunidas naquele volume, do qual "Carbono" é a última história:

Neste ponto, o leitor terá percebido há algum tempo que este não é um tratado de química: minha presunção não chega a tanto [...]. Nem sequer é uma autobiografia, senão nos limites parciais e simbólicos em que é uma autobiografia todo escrito, antes, toda obra humana: mas de algum modo é história. É, ou pretende ser, uma microhistória, a história de um ofício e de suas derrotas, vitórias e misérias, tal como cada um de nós deseja contar quando sente prestes a encerrar-se o arco da própria carreira, e a arte deixa de ser longa. ${ }^{39}$ (LEVI, 2001, p. 225)

A tabela periódica é, portanto, a obra que marca a inserção definitiva do autor no universo literário por dois motivos: o primeiro deles é que 1975, além de ser o ano do lançamento da obra, é também o ano da aposentadoria de Levi da indústria química, e o início da dedicação exclusiva à carreira de escritor. $O$ segundo, é que a obra representará, anos mais tarde - mais precisamente entre o final de 1984 e a primeira metade de 1985 - após a publicação de sua tradução em inglês

${ }^{39}$ Tutti i racconti, p. 569. 
nos Estados Unidos ${ }^{40}$, a porta de entrada para Primo Levi na literatura internacional, e o tornará conhecido mundialmente como um dos principais prosadores da literatura contemporânea, que soube transpor a barreira entre "as duas culturas".

O lançamento da obra na Itália, diferentemente dos livros anteriores, suscitou na crítica um interesse maior, o que gerou diversas resenhas, importantes para entendermos o que significava, naquele momento e naquele contexto, um livro de narrativas breves que, anos mais tarde, seria símbolo da união entre as "duas culturas". Roberto Vacca, por exemplo, dedica uma longa resenha crítica à obra, considerando-o o "melhor livro de Primo Levi", no qual o autor apresenta ao leitor o seu ofício e demonstra que, "muito mais importante do que ter escapado da tragédia, é o fato de ter entendido, explicado, raciocinado os eventos, os homens e as suas motivações" ${ }^{1}$.

Os "elementos-capítulos" da obra de Levi não obedecem a mesma lógica de disposição dos elementos na tabela de Mendeleiev, isto é, não estão na ordem crescente levando em consideração seu peso atômico.

${ }^{40}$ Se questo è un uomo foi traduzido para o inglês em 1959 (por um editor estadunidense com sede em Florença, a Orion Press); La tregua também entrou no mercado anglo-saxônico logo após o seu lançamento, através de uma tradução feita pela editora Bodley Head, de Londres. Porém, foi somente em 1984, com o sucesso de The Periodic Table (tradução de Raymond Rosenthal), publicado primeiro nos EUA, pela Schocken Books, e depois no Reino Unido, pela Michael Joseph, ligada à Penguin, que as obras de Primo Levi conquistaram os leitores de língua inglesa. As entusiasmadas resenhas dos críticos estadunidenses - e, por incrível que pareça, as que mais chamaram a atenção não foram de pessoas ligadas à literatura e sim à ciência - despertaram o interesse do público. A obra foi considerada pelo New York Times Books Review como um dos melhores livros de 1985. Além disso, várias revistas especializadas em química ou ciências em geral citaram The Periodic Table como uma das mais belas obras literárias sobre ciência. Um exemplo: Rudy M. Baum, químico e editor-chefe da Chemical $\mathbb{E}$ Engineering, que publicou no número de 20 de maio de 1985 uma resenha sobre a obra, na qual ele destaca a capacidade do autor em conseguir destacar "a essência do químico e do seu trabalho, bem como a paixão que esse trabalho desperta".

${ }^{41}$ VACCA, R. "Il libro migliore". In: Nazione, 05/07/1975. 
Porém, dentro da sistematização proposta pelo autor, tampouco estão dispostos casualmente, sem nenhuma lógica.

O livro inicia-se com "Argon ${ }^{42}$ ", elemento que aqui estabelece uma função metafórica, pois, nesse primeiro capítulo, o autor fala de suas origens, de seus antepassados, da comunidade judaica de Turim e da sua cultura, afirmando que o pouco que sabe de seus antepassados assemelhase a esse gás, pois a história de sua comunidade era pobre se comparada à história de outras comunidades judaicas da Itália e da Europa. O último capítulo é "Carbono", que conta a história, num andamento descritivoreferencial, de um átomo desse elemento que representa a vida e dilata as perspectivas ao infinito. O "elemento-capítulo" central é "Cério"33", o único que trata da experiência em Auschwitz. Assim como o Lager significa para o autor um "divisor de águas" e representa a experiência central em sua vida, o capítulo "Cério" tem o mesmo papel dentro da lógica de A tabela periódica: divide a obra em duas partes, com dez capítulos anteriores e dez capítulos posteriores; os dez capítulos anteriores narram experiências antes da deportação, enquanto os dez posteriores contam histórias após a liberação. Das dez narrativas anteriores a "Cério", duas são de ficção, e não autobiográficas como as demais - "Chumbo" e "Mercúrio"; assim como, das dez seguintes ao capítulo central, duas também são dessa natureza - "Enxofre" e "Titânio". Apesar de parecer buscar uma simbologia que signifique uma simetria dentro da disposição dos capítulos, não é essa exatamente a intenção do autor: "Chumbo" e "Mercúrio" são, respectivamente, o sétimo e o oitavo capítulos antes do capítulo central, enquanto "Enxofre" e "Titânio" são o segundo e o terceiro após ele. Dessa forma, não podemos dizer que o segundo conjunto de capítulos é uma imagem especular do primeiro, e isso representa, dentro do pensamento de Levi, o fato de que a realidade não

42 O argônio é um gás inerte (argon, em grego, significa “inativo"), elemento da família dos gases nobres, que dificilmente estabelece qualquer combinação química significativa, a não ser em compostos altamente instáveis.

${ }^{43} \mathrm{O}$ cério é um elemento que pertence ao grupo conhecido como "terras raras" que, apesar desse nome, é constituído por elementos não tão raros assim, como é o caso do cério. Abundantemente encontrado na natureza, o cério metálico é pirofórico, podendo inflamar-se quando limado ou atritado. 
é redutível a esquemas perfeitos. Mas, mesmo assim, o desafio do homem, fazendo uso do intelecto, pode tentar interpretá-la e organizá-la, submetêla a uma ordem compreensível que possa demonstrar as suas infinitas potencialidades. E é exatamente este o ofício do químico, que representa, no contexto que o autor dá à obra, o próprio "ofício de viver".

Levi parece, a partir da constatação da ordem dentro daquele universo muito maior de elementos que é a tabela de Mendeleiev, propor uma espécie de "micro-tabela" que, a partir das narrativas construídas constitui-se como nada mais do que uma "micro-história". O universo do laboratório e do mundo do trabalho funciona como um microcosmo, no qual o desafio colocado ao químico é o mesmo desafio colocado ao homem, a partir do momento em que a natureza o dotou de engenho. No capítulo "Ferro", Levi diz:

Que a nobreza do Homem, adquirida em cem séculos de tentativas e erros, consistia em tornar-se senhor da matéria, e que eu me matriculara em Química porque queria manter-me fiel a esta nobreza. Que vencer a matéria é compreendê-la e compreender a matéria é necessário para compreender o universo e a nós mesmos [...]. (LEVI, 2001, p. 47)

A história do átomo de carbono, à qual já fizemos referência e que fecha o livro, é, talvez, a metáfora mais elucidativa do que representa essa micro-história de Levi. O carbono é o elemento mais importante da vida. Obviamente, existem outros elementos sem os quais não haveria vida, mas, desde a coluna em espiral do DNA, até os intrincados anéis e cadeias de esteroides e proteínas, o carbono é o elemento cujas únicas propriedades permitem tudo isso, e não está ligado à experiência no laboratório, mas sim à sua natureza de agente causador da vida humana. As peripécias do átomo de carbono, personagem da história de Levi, dentre as infinitas possibilidades, terminam por encontrar um percurso que vai colocá-lo dentro do corpo do escritor. Esse escritor, que na conclusão da história recebe aquele átomo de carbono de mais de duzentos anos, não é nada mais do que um representante da raça humana, e isso faz com que a história saia do plano autobiográfico para o plano universal, e seja a metáfora explicativa para as demais narrativas.

Ao atribuir a cada conto um título que se refere diretamente a um elemento químico, Levi cria uma simbologia que se liga particularmente 
àqueles fatos, a partir da relação deles com as especificidades da propriedade de cada elemento que o representa no título de cada capítulo, ou ainda, e mais frequentemente, com o papel que aquele elemento tem na narrativa que será apresentada. De fato, todos os elementos estão ali por algum motivo. Funcionam como metáforas, construídas a partir de suas particularidades e propriedades, como é o caso do já citado capítulo "Ferro", que resume as qualidades admiradas por Levi no amigo Sandro Delmastro, forte e determinado, responsável por iniciá-lo no alpinismo - outra paixão do autor. Em outros momentos, os elementos são quase que humanizados ou animalizados, tornando-se personagens dos eventos narrados. Dessa forma, enquanto o Lager era o espaço da "destituição" da personalidade e das particularidades, o universo presente em A tabela periódica parece querer atribuir a cada um dos fatos narrados - e a algumas personagens - aquela particularidade destituída pela experiência concentracionária. Mendeleiev ordenara os elementos de acordo com a individualidade e a particularidade de cada um; Levi ordena suas histórias de acordo com cada um daqueles vinte e um elementos escolhidos por ele, levando em consideração, da mesma forma, a sua individualidade e particularidade, e relação deles com as histórias contadas.

Segundo Belpoliti (2010, p. 46), "o uso da tabela de Mendeleiev para nomear os contos de seu livro não é somente instrumental e conveniente, mas se inspira em um momento da história no qual a química transforma-se, de ciência experimental, em 'ciência escritural', capaz de traduzir a composição do universo no qual vive a humanidade". De fato, Il sistema periodico é a obra mais significativa do autor no que diz respeito à relação entre ciência e literatura e, mais intimamente, entre a química e o fazer literário. Relação esta que está presente em suas outras obras, mas que aqui é explícita e inquestionavelmente mais significativa, pois, diferentemente dos livros de contos anteriores, que recorrem ao fantástico e à ficção-científica, aqui eles se baseiam, em sua maioria, em experiências reais.

Belpoliti (2010, p. 46) observa que uma das intenções do autor é dar "uma ordem constituída à sua existência e à condição humana, ordem que ele encontra na tabela dos elementos de Mendeleiev". As narrativas que constituem a obra são uma espécie de fio responsável por interligar os fatos narrados, significativos no panorama de sua vida até então, demonstrando a confiança na ciência e na razão, na sede de conhecer, que sempre fez parte de sua vida. 
Levi, assim, busca humanizar a ciência, lançando mão de um estilo que se aproxima - e muito - daquele do relatório científico, descritivo e explicativo. Além disso, Levi não só promove uma espécie de humanização dos objetos da ciência, mas também os utiliza como filtros metafóricos, pois os termos utilizados muitas vezes não se referem exatamente ao trabalho no laboratório ou à química, mas a ações ou a personagens. $O$ fato é que, dentro da totalidade das narrativas, as que não são autobiográficas não apresentam tecnicismos relativos à química: "Chumbo", "Mercúrio", "Titânio" e "Enxofre". E, considerando o conteúdo de todas as histórias, não podemos perder de vista a intenção do autor de discorrer sobre os desafios de sua profissão que, metaforicamente, são os desafios do próprio ser humano diante da realidade que o cerca.

Até então, a literatura de Levi havia se desenvolvido a partir de duas vertentes que a crítica costumou separar: de um lado os seus relatos como prisioneiro, e depois, sobrevivente de Auschwitz; de outro, os contos de fantasia científica e tecnológica. Mesmo considerando que nas quatro obras anteriores o hibridismo está também presente, ilustrado pela variedade de gêneros que nos são apresentados, não podemos deixar de afirmar que, em A tabela periódica, tal hibridismo está igualmente contemplado na polifonia de gêneros que, definitivamente, iria marcar a literatura do autor: somam-se às narrativas de tom autobiográfico outras, de ficção, mas que têm em comum com aquelas a matéria-prima da qual provêm, isto é, a química e o universo do trabalho dos químicos.

As narrativas memorialistas de A tabela periódica, partindo da necessidade e da vontade de dividir experiências, têm a intenção de narrar momentos significativos da vida de Levi. Assim sendo, as narrativas que constituem esse volume e que se referem diretamente à química e ao ofício de químico são extremamente significativas quando analisamos as considerações do autor acerca do mundo do trabalho. Podemos dizer que, em A tabela periódica, Levi planta a semente daquilo que iria tratar com mais detalhes em sua obra posterior, A chave estrela (1978), livro no qual o trabalho liberatório, através da técnica e de seu aprimoramento, será exaltado como parte integrante e indissociável do homem, sendo essencial para determinar o seu destino na vida sobre a Terra.

A obra, que traz trinta e dois anos de experiência pessoal do autor, entre 1935 e 1967, seria aclamada, como já citado, como o melhor livro de divulgação científica de todos os tempos. Ao lado de outros escritos com conteúdo científico, a obra é frequentemente citada como um 
modelo de eficaz divulgação científica e didática da ciência. Isso porque, baseado no que se diz entre o meio científico, ela promoveu, entre o grande público, a divulgação de alguns fundamentos básicos da química, relacionando as narrativas às características dos elementos da tabela periódica. Podemos dizer que a intenção inicial de Primo Levi parecia ser compor uma obra literária que comprovasse que a química não era um terreno árido para a literatura: o intuito primordial na concepção da obra parece ser o de destacar o aspecto apaixonante presente em sua ciência, afinal, para ele, "a química era algo que servia para tudo: para cultivar-se, para crescer, para se inserir, de qualquer forma, nas coisas concretas, para se educar". (POLI; CALCAGNO, 2013, p. 57)

Cada elemento químico, segundo Levi afirma no início de "Carbono", deve significar algo para alguém - e para cada pessoa, algo diverso - assim como uma paisagem tem um significado para aquele que a vê ou que dela se recorda. Tal afirmação parece ser exatamente aquilo que Levi desejava construir: uma narrativa romântica, no que diz respeito ao sentimento que o autor nutria por aquilo que se configurava como a matéria de suas histórias, que levasse em consideração o amor que ele sentia pela química, o desafio estabelecido pela matéria - mãe e inimiga - e o sentimento ligado ao seu trabalho de separador e construtor de moléculas. A paixão demonstrada pela ciência e pelo ofício, não somente nas narrativas reunidas nesse volume, mas que invade praticamente toda a sua obra, reflete-se em seu estilo claro, coeso e conciso, o qual preza pela racionalidade e paciente construção.

A química é, para Levi, a responsável por colocar ordem no caos, sistematizar o universo, explicá-lo. Mas, ao mesmo tempo, é uma paixão arrebatadora, quase romântica, ainda mais para o jovem que, ainda nos anos do liceu, enxergava os encantamentos daquele primeiro amor. Em A tabela periódica, mesmo que de maneira comedida, na maioria das vezes, é dessa paixão e dessa relação íntima que Levi irá nos falar.

O livro atingiu um sucesso significativo de público, com $32 \mathrm{mil}$ cópias vendidas em um ano, e foi inserido na lista de livros para a escola média, em 1979, acompanhado de um prefácio de Natalia Ginzburg e de notas elaboradas pelo próprio autor, que esclarecem algumas citações e, sobretudo, explicam conceitos relacionados à química e à história. Além disso, foram suprimidas do texto, na edição escolar, episódios ou frases que, na visão do autor, poderiam ser impróprias para os jovens leitores aos quais a edição era dirigida. 
Dessa forma, constituindo-se como um dos pontos em torno dos quais giram não só a vida e o trabalho de Primo Levi, mas também, e significativamente, sua literatura, podemos dizer que a química é um dos motivos pelos quais ele saiu vivo do campo de concentração, pois, como relata em É isto um homem?, foi após o exame de química que acabou sendo admitido no Kommando químico, dessa forma, ficou no laboratório da Buna ${ }^{44}$ nos dois últimos meses de reclusão.

Belpoliti (2010, p. 45) cita um estudioso, Gianlorenzo Marino, professor universitário de química e grande admirador da obra de Primo Levi, que fez um levantamento a respeito da quantidade de elementos químicos ou coisas ligadas ao estudo da química que a obra de nosso autor condensa. Marino encontrou, afora os vinte e um elementos da tabela de Mendeleiev que dão nome aos capítulos do autobiográfico A tabela periódica, mais cinquenta e oito elementos da química citados por Levi, em um total de trezentas e setenta e sete citações. Stefano Colonna (2004, p. 25), por sua vez, afirma que as palavras "química" e "químico" aparecem cerca de trezentas vezes nos escritos de Levi, enquanto as palavras ligadas a seu ofício de formação passam de mil registros: além dos nomes dos elementos, aparecem os nomes dos "instrumentos, operações fundamentais da manipulação de laboratório, compostos orgânicos e inorgânicos".

A química, pois, é uma das chaves que dão acesso a questões centrais na literatura de Primo Levi. Dessa forma, alguns dos conceitos básicos da química são recorrentes e extremamente úteis para a análise interpretativa de sua obra. Aqui, destacaremos um deles: o binômio pureza/ impureza:

44 O laboratório de Buna-Monowitz era controlado, numa cooperação entre o governo nazista e algumas indústrias químicas alemãs, pela I.G. Farben. Abreviatura de Interessen-Gemeinschaft Farbenindustrie, a I. G. Farben foi um grande cartel formado pelas principais indústrias químicas alemãs em 1925, que patrocinou a ascensão do partido nazista na Alemanha e serviu como apoio logístico para as ações do exercito alemão. Constituído pelas principais indústrias Alemãs, o cartel I.G. Farben foi desfeito 1945 por determinação dos aliados, voltando as indústrias a se organizarem e trabalharem de forma independente. A partir de então Basf, Bayer e Hoescht são indústrias autônomas que competem entre si. 
Na química, a pureza (ou melhor, o grau de pureza) de uma substância, simples ou composta, é a relação percentual entre a quantidade da substância em análise e a quantidade de substâncias totais presentes em uma amostra. Para um composto orgânico, a pureza é determinada, frequentemente, através da medida de algumas constantes físicas (ponto de fusão ou de ebulição, peso específico etc.) típicas do composto puro e que se modificam pela presença de quantidades, até muito pequenas, de substâncias estranhas. No caso de macromoléculas biológicas, o índice ou grau de pureza é medido com métodos analíticos como a eletroforese, a cromotografia etc. (DI MEO, 2011, p. 99, tradução nossa)

A matéria pressupõe a impureza, e tudo no mundo supõe tal propriedade. A vida, para Levi, é contaminação, cruzamento, mistura, composição, hibridação. Ou seja, a impureza é vista como vital e não se pode falar de "pureza da raça", por exemplo. Obviamente, o tema da impureza está intimamente ligado ao judaísmo na literatura de nosso autor. Ao determinar a inferioridade da "raça hebraica", por exemplo, o fascismo ignora a prioridade dos aspectos biológicos que determinam a raça, apegando-se a um dogmatismo construído a partir de uma ideologia. Dessa forma, dizer que existe entre os seres humanos uma separação de "raças", e que uma é mais "pura" do que outra, é ignorar características abundantemente encontradas nos seres naturais, tais como a miscigenação e o hibridismo. A impureza supõe o hibridismo, característica evocada por Levi mais de uma vez (LEVI, 1997, pp. 185186): "Eu creio que meu destino profundo seja o hibridismo, a divisão: italiano, mas judeu, químico, mas escritor”. Para Levi, ser híbrido é ser impuro, e ser impuro é um fator da natureza, que nega todas as teorias do nazismo para a busca de uma "raça pura e superior".

A química, que estuda a estrutura e as propriedades da matéria, experimentalmente dedica-se ao comportamento das moléculas submetidas a estímulos físicos (temperatura, corrente elétrica etc.) e químicos (reações); pode ser considerada a chave para entender a vida, o nosso planeta e a sua geologia. Assim sendo, podemos dizer que, dessas perspectivas, nasce um dos objetivos da literatura de Primo Levi: assim como a química diante da matéria e do comportamento das moléculas, a literatura do autor, em sua totalidade, e na diversidade de seus gêneros, 
propõe-se a analisar, sobretudo, o comportamento do homem nas mais diversas situações, das quais o Lager pode ser considerado o exemplo mais extremo e radical. Levi demonstra-se um etólogo, analisando comportamentos e situações, apresentando personagens curiosas e estabelecendo questionamentos. Invoca para si o papel de observador, afinal, a fonte principal de sua literatura é a observação. A observação é também característica primordial do químico, que deve possuir a astúcia dos olhos e a fina capacidade de raciocínio a partir daquilo que se apresenta diante de seus olhos. Mais propriamente na literatura de testemunho, Levi, dramaticamente, está dentro e fora, observa e é objeto da própria observação, e, no caso do último livro sobre o Lager, Os afogados e os sobreviventes (1986), que é também sua última obra, coloca em evidência a própria maneira de observar.

Por fim, podemos dizer que a química é, direta ou indiretamente, uma das causas da salvação de Levi do campo de concentração. Apesar de o autor quase sempre imputar a sua salvação à sorte, por vezes ironicamente, sabemos que a sua admissão no laboratório químico da Buna é de fato um dos motivos que o fazem sair vivo de Auschwitz: "Tive sorte, por ser químico” (CAMON, 1997, p. 71). A química é a metáfora preferida de Levi na análise do comportamento humano, bem como na análise da condição humana; povoa sua literatura, com o intuito de descrever e tentar explicar os aspectos mais incompreensíveis do humano. Assim, enquanto químico, seu desafio maior era em relação à matéria: entendê-la, penetrá-la em sua composição, distinguir seus elementos, desvendá-la. Enquanto escritor, Levi entendia que, através do seu "escrever claro", colocava ao leitor o mesmo desafio em relação à vida e ao mundo que o cercava. Lançando mão da escrita clara e concisa, do escrúpulo de exatidão que o acometia, tentava através de sua literatura compreender criticamente os eventos, esclarecê-los, elucidá-los. A química é, enfim, metáfora para a criação linguística e para a observação dos eventos, de modo que, em hipótese alguma, deve desvencilhar-se da análise e da crítica relativa à literatura de Primo Levi. E, exatamente por isso, na análise que nos propomos a fazer a seguir, a ciência e a química estarão sempre presentes. 


\section{REFERÊNCIAS}

ANTONELLO, P. Il ménage a quattro: Scienza, filosofia, tecnica nella letteratura italiana del Novecento. Firenze: Il Monnier, 2005.

BARTEZZAGHI, S. Una telefonata con Primo Levi. Torino: Einaudi, 2012.

BELPOLITI, M. Primo Levi. Milano: Mondadori, 2010.

BELPOLITI, M. Primo Levi di fronte e di profilo. Milano: Ugo Guanda Editore, 2015.

CALVINO, I. Assunto encerrado. Discursos sobre literatura e sociedade. Tradução de Roberta Barni. São Paulo: Companhia das Letras, 2009.

CAMON, F. Conversazione con Primo Levi. Parma: Guanda, 1997.

CESERANI, R. Convergenze: gli strumenti letterari e le altre discipline. Milano: Mondadori, 2010.

DE GRAZIA, V.; LUZZATO, S. Dizionario del Fascismo. Torino: Einaudi, 2005, v.1 e v.2.

DI MEO, A. Primo Levi e la scienza come metafora. Soveria Manelli: Rubbettino, 2011.

ECO, U. Apocalipticos e integrados. 6ed. Trad. Pérola de Carvalho. São Paulo: Perspectiva, 2008.

LEVI, P. A tabela periódica. Tradução de Luiz Sergio Henriques. Rio de Janeiro: Relume-Dumará, 2001.

LEVI, P. Conversazioni e interviste. Torino: Einaudi, 1997.

LEVI, P. L'altrui mestiere. Torino: Einaudi, 2011.

LEVI, P. Opere. V.3.Torino: Einaudi, 2018.

LEVI, P.; REGGE, T. Dialogo. Torino: Einaudi, 2005.

MONTESPERELLI, F. Tra Frankenstein e Prometeo: miti della scienza nell'immaginario del '900. Napoli: Liguori, 2006.

POLI, G.; CALCAGNO, G. Echi di una voce perduta: incontri, interviste e conversazioni con Primo Levi. Torino: La Stampa, 2013.

PORRO, M. La cultura ibrida di Primo Levi. In: . Letteratura come filosofia naturale. Milano: Medusa, 2009.

PORRO, M. Scienza. In: BELPOLITI, M. (org.). Riga. Milano: Marcos y Marcos, 1997.

ROTH, P. Chiacchiere di bottega. Torino: Einaudi, 2004.

SNOW, C.P. As duas culturas e um segundo olhar. Tradução de Renato Rezende Neto. São Paulo: EDUSP, 1993. 
126 |Aislan Camargo Maciera

Recebido em: 02/08/2019

Aceito em: 14/09/2019

Caderno de Letras, no 34, Maio-Ago - 2019 - ISSN 0102-9576 